\section{Noticias y comentarios}

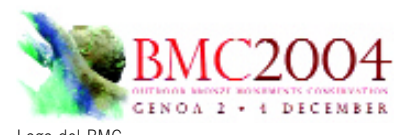
Logo del BMC
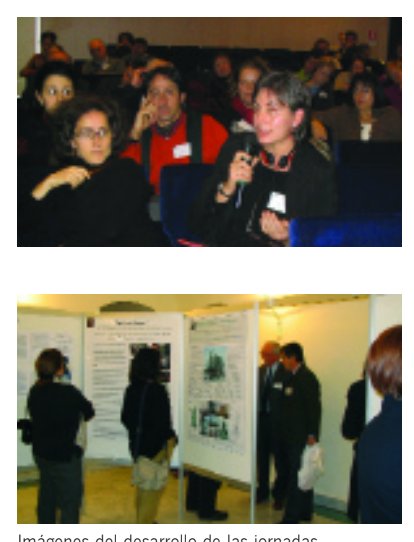

Imágenes del desarrollo de las jornadas

\title{
Expertos internacionales en conservación de bronce al aire libre se reúnen en Italia
}

Conservación de monumentos de bronce al aire libre: experiencias a debate es el título del seminario BMC2004 (Bronze Monuments Conservation), celebrado en Génova (Italia) en diciembre de 2004 para debatir, a nivel europeo, acerca de la conservación de los bienes culturales en bronce expuestos al aire libre. El objetivo del seminario era contrastar las distintas experiencias y conocimientos adquiridos sobre la materia, fomentando el diálogo entre todas las disciplinas que participan en la gestión de los bienes y que desarrollan un papel particular en el contexto urbano. Las jornadas de trabajo han contado con la participación de unos 140 profesionales (entre investigadores, restauradores, historiadores del arte, técnicos y funcionarios públicos) procedentes de distintos paises europeos y de los Estados Unidos.

El seminario se desarrolló durante tres días, y cada una de las jornadas se centró en un tema específico. El primer día se trataron los aspectos normativos y de carácter histórico-artístico a partir de la revisión de la legislación específica existente y de los documentos internacionales, analizando las cuestiones relacionadas con la vinculación entre sociedad y monumentos de bronce al aire libre, y reflexionando sobre el significado y el papel de la pátina. La segunda jornada se dedicó al análisis de los métodos técnico-científicos, como los empleados en los laboratorios para los objetos de bronce, o las técnicas utilizadas en las operaciones de investigación, limpieza, protección que son necesarias en las intervenciones de conservación y restauración. El último día se hizo un repaso a las distintas experiencias llevadas a cabo en otros países europeos, ofreciendo una visión amplia y rica de problemáticas, métodos de intervención y técnicas adoptadas en la conservación.

Las contribuciones aportadas por los ponentes se han recogido en el libro Monumentos de bronce al aire libre. Experiencias de conservación a debate (que incluye un CD con fotografias) publicado por Nardini Editores (Florencia), dentro de la colección "Arte y Restauración" (ver www.nardinieditore.it).

Al ser una de las finalidades del seminario ofrecer una sintesis de las experiencias compartidas y reflexionar sobre las cuestiones sin resolver en el sector, los resultados y conclusiones alcanzadas en las mesas redondas han sido de gran interés por la gran implicación de los participantes. En la mesa redonda de clausura se discutió la elaboración de un documento que reflejase y recogiese las recomendaciones y procedimientos más adecuados para la conservación, restaura- ción y la preservación de los bronces al aire libre, indicando los principales problemas sin resolver sobre los que centrar los esfuerzos futuros, de manera que sirviese de sintesis de todas las conclusiones surgidas en el transcurso del seminario. Por otro lado, también se consideró adecuado crear un mailing que ofreciese un foro de discusión específico sobre el tema de la conservación del bronce al aire libre a nivel internacional (http://nameserver.ge.cnr.it/mailman/listinfo/ bmclist). Este mailing ha servido para continuar con el trabajo de redacción del documento final, documento que ya está disponible para su consulta en la página web del seminario (www.bmc2004.org). Aunque recomendamos la lectura del documento completo para tener una visión global, podemos destacar algunas de las conclusiones:

$>$ La necesidad y utilidad de integrar las prácticas de preservación de forma frecuente y constante en el tiempo para lograr una conservación más eficaz, tanto desde el punto de vista de la calidad de los resultados como la reducción de costes a largo plazo que conlleva.

$>$ La importancia de fomentar e incrementar siempre el diálogo entre los distintos profesionales implicados, con el fin de desarrollar una aproximación multidisciplinar al objeto de estudio necesaria para la transmisión de nuestra herencia cultural a las generaciones futuras.

$>$ La necesidad de incrementar el intercambio de documentación existente sobre experiencias de conservación y restauración del bronce al aire libre, haciendo uso de los instrumentos informáticos que tenemos a disposición, junto a la utilidad de elaborar una guía específica de buenas prácticas aplicables a este sector.

$>$ Es importante destacar dos aspectos que requieren una especial atención y en los que habría que profundizar porque son cuestiones sin resolver: a) la reversibilidad de los materiales empleados, sobre todo aquéllos usados en la manufactura en metal; b) la evaluación de la pátina, desde el punto de vista técnico, diagnóstico y estético, desarrollando también estudios y comparaciones entre metodologías de limpieza con base científica.

Paola Letardi

Comité Organizador

Istituto di Scienze Marine (ISMAR) 